\title{
Water displacement by sewer infrastructure in the Grote Nete catchment, Belgium, and its hydrological regime effects
}

\author{
D. Vrebos ${ }^{1}$, T. Vansteenkiste ${ }^{2}$, J. Staes ${ }^{1}$, P. Willems ${ }^{2,3}$, and P. Meire ${ }^{1}$ \\ ${ }^{1}$ Department of Biology, Universiteit Antwerpen, Universiteitsplein 1, 2610 Wilrijk, Belgium \\ ${ }^{2}$ Department of Civil Engineering, KU Leuven, Kasteelpark Arenberg 40, 3001 Leuven, Belgium \\ ${ }^{3}$ Department of Hydrology and Hydraulic Engineering, Vrije Universiteit Brussel, Pleinlaan 2, 1050 Brussel, Belgium
}

Correspondence to: D. Vrebos (dirk.vrebos@uantwerpen.be)

Received: 13 May 2013 - Published in Hydrol. Earth Syst. Sci. Discuss.: 12 June 2013

Revised: 8 February 2014 - Accepted: 13 February 2014 - Published: 26 March 2014

\begin{abstract}
Urbanization and especially increases in impervious areas, in combination with the installation of wastewater treatment infrastructure, can impact the runoff from a catchment and river flows in a significant way. These effects were studied for the Grote Nete catchment in Belgium based on a combination of empirical and model-based approaches. Effective impervious area, combined with the extent of the wastewater collection regions, was considered as an indicator for urbanization pressure. It was found that wastewater collection regions ranging outside the boundaries of the natural catchment boundaries caused changes in upstream catchment area between -16 and $+3 \%$, and upstream impervious areas between -99 and $+64 \%$. These changes lead to important intercatchment water transfers. Simulations with a physically based and spatially distributed hydrological catchment model revealed not only significant impacts of effective impervious area on seasonal runoff volumes but also low and peak river flows. Our results show the importance, as well as the difficulty, of explicitly accounting for these artificial pressures and processes in the hydrological modeling of urbanized catchments.
\end{abstract}

\section{Introduction}

Urbanization significantly impacts flow regimes and water quality of river systems (Paul and Meyer, 2001; Jacobson, 2011). In particular, impervious areas exert several pressures on the hydrological cycle of catchments (Shuster et al., 2005). They affect infiltration, surface runoff and evapotranspiration, making the lateral processes potentially more important in urban settings than the vertical processes (Arnold and Gibbons, 1996; Becker and Braun, 1999; Brabec, 2009). These alterations in hydrological processes increase runoff peak flows and flood flashiness in rivers (Sheeder et al., 2002; Baker et al., 2004).

The effects of urbanization on peak flows have been studied in more detail compared to its effects on baseflow and low-flow events (Price, 2011). Baseflow represents stream flow fed from deep subsurface and delayed shallow subsurface storage (Ward and Robinson, 1989), while low flow addresses dry season minimum flows (Smakhtin, 2001; Price, 2011). As urbanization reduces infiltration and recharge, it is generally expected that river baseflow is affected as well (Simmons and Reynolds, 1982; Kauffman et al., 2009). Baseflow can, however, also be strongly influenced by various types of anthropogenic activities in the catchment, such as water abstractions, sewer leakage or groundwater intrusion (Seiler and Rivas, 1999; Smakhtin, 2001; Brandes et al., 2005; Wittenberg and Aksoy, 2010). Hence, the impact of urbanization on the different flow regimes is difficult to detect due to the strong temporal flow variations (weak signal-tonoise ratio). Although a weak tendency in baseflow decline and peak flow increase has been identified by some authors (Price, 2011), the combined effect of several anthropogenic and natural processes that influence baseflow and differences in assessment methodologies result in many remaining uncertainties in our understanding of baseflow behavior in periurban catchments (Hamel et al., 2013).

Sewers collect wastewater and, for combined sewer systems, also rainstorm water from pavements. They can also receive groundwater or leak wastewater to the groundwater 
system (Dirckx et al., 2009). The collected water is transported to a wastewater treatment plant (WWTP) and, after treatment, discharged into a receiving river. The WWTP thus aggregates water from the entire wastewater collection region (WWCR) and returns it to the environment at one single river location. Moreover, the WWCRs usually do not coincide with the catchment boundaries as they are mostly based on administrative borders. Consequently the associated sewer infrastructure might transfer water between different natural (sub)catchments and further affect the natural hydrological processes in the catchment (Simmons and Reynolds, 1982). Recent research on catchment delineation considered incorporation of these changes in hydrological flow paths using semi-automated procedures (Jankowfsky et al., 2013). Such delineations, however, remain largely data dependent and time consuming.

Total impervious area (TIA) is considered to be an important indicator of the urban disturbance and an important land use characteristic. Imperviousness of urban areas is, however, very heterogeneous. Infiltration of impervious areas may not always be zero (Ragab et al., 2003). Impervious areas that are directly connected to the receiving river have a much larger effect on that receiving river (Boyd et al., 1994; Walsh et al., 2009). Some studies therefore suggest that the subset of impervious surfaces that route storm water runoff directly to streams via storm water pipes, also called effective impervious area (EIA), may be a better predictor of stream flow alteration (Shuster et al., 2005; Roy and Shuster, 2009). Measurements of EIA are, however, much more difficult to obtain and therefore less commonly used in hydrological studies (Walsh et al., 2009).

Some studies have accounted for the difference between TIA and EIA in impact studies (Lee and Heaney, 2003; Shuster et al., 2005). The traditional calculation of TIA and EIA might, however, be erroneous since the difference in boundaries between the natural river catchment and the WWCRs is typically disregarded. When impervious areas are situated within a river catchment, the surface runoff from these areas might drain to a WWTP located outside the catchment. The impervious areas in that case do not contribute to the runoff of the considered catchment.

Next to empirical statistical analysis, hydrological models can offer additional methods for studying the impact of changes in pervious and impervious areas on catchment hydrology. Such models can indeed help in complementing existing data and obtaining a better insight in the hydrological behavior of a catchment and the hydrological impact of urbanization. To allow the impact of spatial (e.g., landuse-related) scenarios to be assessed, fully spatially distributed hydrological process models (FDPM) are required. Such models give a spatially detailed and potentially reliable description of the hydrological processes in the catchment (Abbott and Refsgaard, 1996; Refsgaard and Knudsen, 1996; Boyle et al., 2001; Ajami et al., 2004; Carpenter and Georgakakos, 2006), but require a high amount of spatially explicit input data. After calibration of the large set of parameters in such models, a better match between simulated and observed hydrological variables may be obtained, but this does not necessarily mean that the model has a good accuracy. Model over parameterization and related parameter identifiability problems are well-known pitfalls (Beven, 1989; Jakeman and Letcher, 2003; Muleta and Nicklow, 2005). These problems limit the applicability of such models. The FDPMs perform well in catchments where the hydrological processes are still close to natural runoff conditions, but are typically less accurate in urban areas due to the several (unknown or difficult to model) human influences (Vansteenkiste et al., 2013).

Discarding these anthropogenic influences can lead to a significant model bias and related impact assessments. In an urbanized environment with extensive sewer infrastructure, this might not only affect the performance of the catchment runoff and river flow simulation; it can also have indirect effects on parameterization of other land uses and over- or underestimate individual runoff components (Vansteenkiste et al., 2013). It has previously been demonstrated that if one does not differentiate between TIA and EIA in the hydrological model, this may result in a large model bias (Alley and Veenhuis, 1983; Brabec, 2009). EIA is the most sensitive flow parameter in urban drainage models. Some authors have shown that calibration of this parameter may completely eliminate the bias in the results of these models (Willems and Berlamont, 1999; Kleidorfer et al., 2009).

This paper aims to quantify the importance of interbasin transfers and WWTP effluent flow contributions to downstream river flows for a selected river catchment in Belgium. The study makes use of measured river flows and effluent discharges from the different WWTPs installed in and outside the catchment. We evaluate the relative contribution of these WWTPs to the river flow, including peak and low flows. To understand the origin of the WWTP effluent discharges and the WWTP-induced water transfers between catchments, the sewer infrastructure and the EIA are assessed in a GIS environment, and compared with FDPM simulations for the study catchment. When implementing the FDPM, the abovementioned modeling issues (e.g., impervious area calculation and interbasin transfers) are considered. Based on empirical data analysis, model-based results and the comparison between both; we demonstrate the magnitude and importance of

- water transfers across the catchment boundaries,

- water transfers across subcatchments within the catchment,

- the impact of EIA on river high and low flows and the performance of an FDPM.

We also discuss the implications the water transfers have on the FDPM-based impact analysis. 


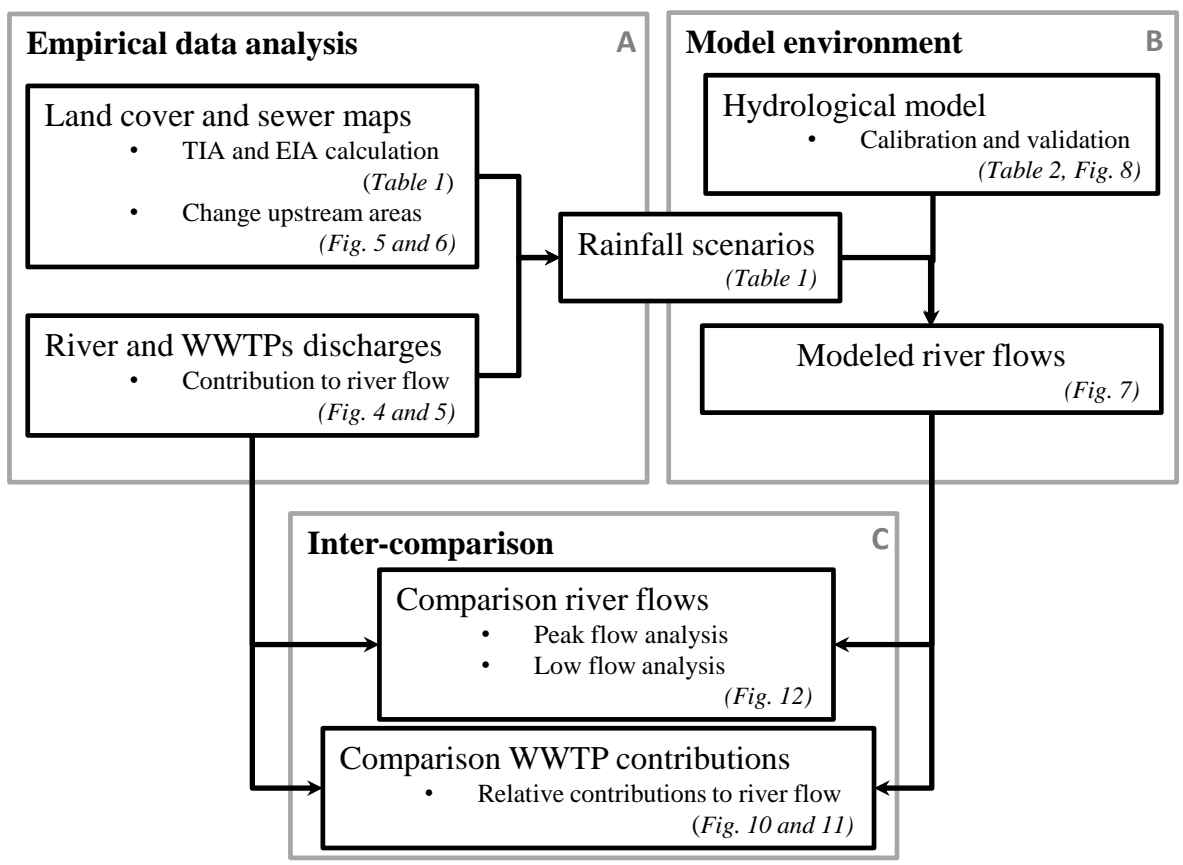

Fig. 1. General overview of the different steps of the research methodology and their interlinks.

\section{Material and methods}

\subsection{Study area}

The study catchment the Grote Nete river $\left(350 \mathrm{~km}^{2}\right)$ is situated in the north of Belgium. It has a maritime, temperate climate with average precipitation of $800 \mathrm{~mm}_{\text {year }}{ }^{-1}$. The catchment is composed of a mosaic of semi-natural, agricultural and urbanized areas, with a total population of 218815 (Statistics Belgium, 2011). Urbanized areas are mainly situated around the town centers, but important parts of the urbanization are spread along the main roads connecting the different towns. As a result the development of the sewer infrastructure is difficult, costly and time consuming.

Although the first WWTP in the catchment dates back from 1964, major investments in the sewer infrastructure only started 15 to 20 years ago (Dirckx et al., 2009). Nevertheless, large numbers of households are yet to be connected to the sewer infrastructure. The sewer system consists mostly of a combined system that collects both rain- and wastewater and is connected to sewer overflow devices (SOD) that are present at several locations in the catchment. Only a small, more recent part of the sewer system separates rain- and wastewater. Houses that are not yet connected to a sewer usually have a sceptic tank for basic treatment, after which the overflow drains to the nearest stream. The historical developments in the region and of the sewer system have led to a complex situation of connected and non-connected houses, roads and other impervious areas with or without rainwater separation.

\subsection{Overview of the research approach}

The approach and procedure to demonstrate the impacts of EIA connected to WWTPs and how they interlink in order to answer the research questions is visualized in Fig. 1. (A) As a first step, empirical quantification and analysis of the impervious areas as well as the river and WWTP discharges was carried out (further referred to as the empirical analysis). (B) The empirical data of both EIA and WWTP discharges were used to develop three reduced rainfall scenarios and simulated in an FDPM to model the river flows in the catchment. (C) The empirical and modeled river flows and impacts of the WWTP impacts were intercompared in order to obtain an improved understanding of both catchment and model behavior.

\subsection{River flow and WWTP discharges}

The Flemish Environment Agency (FEA) provided both hourly and daily mean river flow data $\left(\mathrm{m}^{3} \mathrm{~s}^{-1}\right)$ for the river gauging station situated at the outlet of the catchment (Varendonk) for the period 2004-2008, as well as effluent discharge data for the different WWTPs that are related to the catchment (Fig. 2). To evaluate the overall impact of the WWTPs that discharge into the catchment (Mol and Geel), relative contributions of the WWTPs effluent discharges to the daily discharge of the Grote Nete river were calculated for the period 2004-2008. No discharge data were available for the WWTP of the military camp of Leopoldsburg. However, because of its small size ( $0.7 \%$ of total EIA), its impact on the 


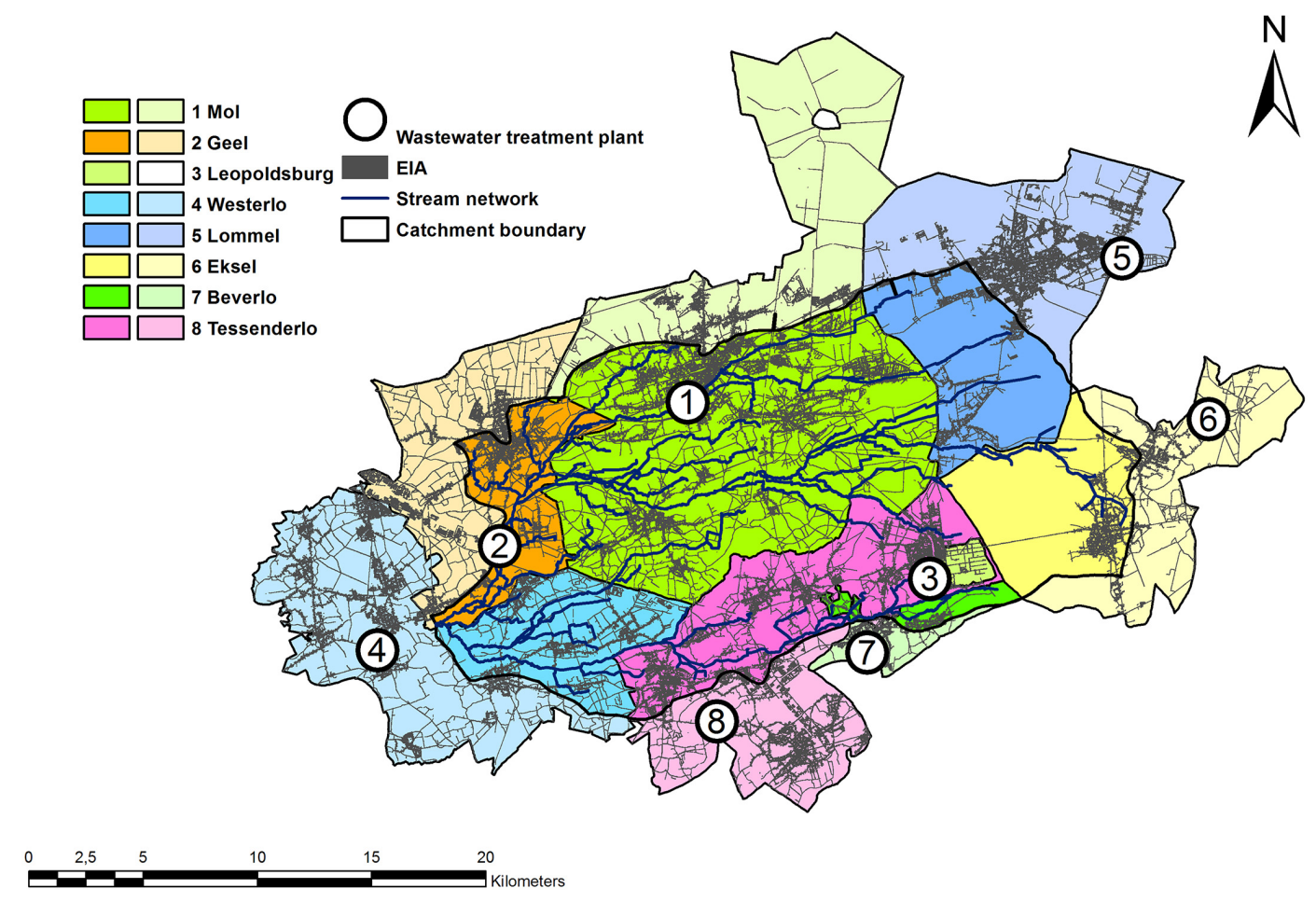

Fig. 2. Overview of the different WWTPs and their WWCRs that are situated within the Grote Nete catchment (1-3) as well as the WWTPs that receive wastewater from impervious areas that are situated within the Grote Nete catchment but discharge into another catchment (4-8). Parts of the WWCR that are situated within the natural catchment boundary are shown with a brighter shade, illustrating the discrepancy between the areas covered by the natural catchment and the sewer systems.

river system is considered to be negligible. The hourly river flow data were used for model calibration and validation.

\subsection{Land use map and impervious area}

The land use map used in this study was obtained from the National Geographical Institute (NGI) (NGI, 2007) and has a spatial accuracy of $1 \mathrm{~m}$. This land use map $(1: 10000$ vector layers) is based on aerial photographs from 1998 $(1: 21000)$, ground-truthed and adjusted in the following years until 2007, when the map was published. It contains 47 different land uses. For the hydrological simulation purposes, a reduced set of nine categories was considered: evergreen needleleaf forest, broad-leaved woodland, mixed forest, open scrublands, grasslands, permanent wetlands, croplands, impervious area and water bodies (Table 1). These nine classes follow the IGBP classification system based on their relationship to the modeled hydrological processes (Liu and De Smedt, 2004). Impervious areas include only completely sealed soils. Areas that can have reduced infiltration rates such as sandy roads (sand) or gardens are not considered to be part of the impervious areas. They are classified based on the most common characteristics of each land use type in the region (e.g., gardens are most often lawns).

The EIA is estimated on the basis of two thematic GIS layers representing the sewer system areas and are based on field observations done by different administrations. Houses connected to the sewer system are shown in zoning maps (one for each municipality). These maps indicate the connection of all individual households to the sewer systems and which ones drain directly to a nearby stream. The zoning maps also indicate which houses will be connected in the future and which buildings will have to install individual wastewater treatment plants (FEA, 2008b). In order to conduct all analyses based on the same input data, the zoning maps were used to identify the buildings, present in the NGI land use map, connected to each sewer system.

Streets that are connected to the sewer system were identified based on the polylines describing each sewer system (FEA, 2008a). Streets in the NGI land use map that overlap with the sewer system were assumed to contribute to the EIA. Sewers that separate waste- and rainwater were left out from this part of the analysis. Combining both methods resulted in one map from which the EIA of each WWCR was derived.

\subsection{Upstream area calculations}

Subcatchments were delineated based on a $1: 5000$ digital elevation model (DEM) expressed as a $5 \mathrm{~m}$ raster (FEA, 2005, 2006). For each stream junction $(n=131)$, upstream areas were calculated using the method discussed in Jenson and Domingue (1988) (further referred to as the runoff method). 


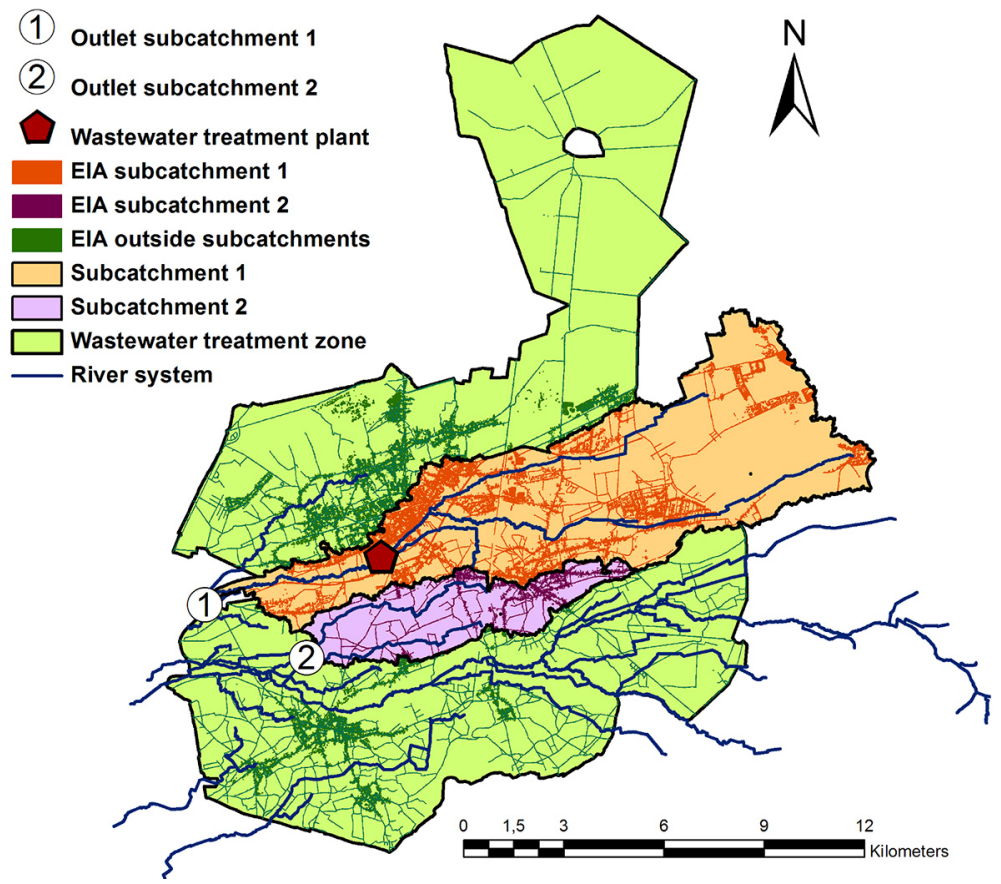

Fig. 3. Example on the calculation of the upstream areas. The WWTP discharges into subcatchment 1 (orange colored). Therefore the EIAs within the WWCR, but outside subcatchment 1 (green and purple colored), are included in the upstream area of subcatchment 1 . As a result the area of this subcatchment increases by 404 ha of impervious area or by $5.1 \%$ of the total area. Because the EIA is removed from subcatchment 2 (purple color), the area of subcatchment 2 decreases by 69 ha or $4.3 \%$ of the total area.

By combining these upstream areas with the $1 \mathrm{~m}$ raster of the land use map, we calculated upstream impervious area for each stream junction.

Next the sewer infrastructure was considered (further referred to as the sewer method) (Fig. 3). In this method, the upstream areas were recalculated by removing the EIAs from their natural subcatchments and adding these EIAs to the subcatchment of the river reach into which the WWTP discharges. As zoning maps also indicate which houses yet have to be connected to the WWTPs, expected upstream areas for the near future were obtained as well. Differences in upstream impervious areas and total areas between the runoff method and the sewer method were considered as indicators of how strongly the catchment is affected by the sewer infrastructure. All GIS calculations were performed in ArcGIS 9.3 (ESRI Inc., 2009).

To make an evaluation of the impact of the sewer infrastructure on the catchment's overall water balance, the changes in upstream area and upstream impervious areas (TIA) between both methods were calculated for the 131 stream junctions in the catchment. The relative changes (\%) were analyzed by means of histograms.

\subsection{MIKE SHE model setup}

MIKE SHE is a spatially distributed, physically based hydrological model (Abbott et al., 1986). It simulates the terrestrial water cycle including evapotranspiration (ET), overland flow, unsaturated soil water and groundwater storage and movements (Refsgaard and Storm, 1995; Feyen et al., 2000; DHI Water and Environment, 2008). The MIKE SHE model has been used worldwide for a wide range of applications (Refsgaard, 1997; Sun et al., 1998; Thompson et al., 2004; Sahoo et al., 2006; Zhang et al., 2008). For this study, a spatially distributed, physically based hydrological model was selected over other types of hydrological models as it can simulate the effect of spatially differentiated scenarios. It allowed us to evaluate the effect of changes in spatial patterns of surface runoff on the hydrological regime. The model was also used for other research purposes (Vansteenkiste et al., 2013) The representation of catchment characteristics and input data (digital terrain model, land use, soil) in MIKE SHE are provided through raster information. The MIKE SHE model for the Grote Nete catchment was built on a $250 \mathrm{~m}$ grid. It was developed with physics-based flow descriptions only for those processes that are relevant for the purposes of this study, i.e., overland and unsaturated flow. Given that the study focusses on spatial scenarios at the surface (changes in surface runoff), groundwater flow processes are considered to be secondary. Therefore the saturated zone was implemented through simplified lumped process descriptions, while surface processes were modeled in a spatially variable way (see Vansteenkiste et al., 2013, for details). The applied 


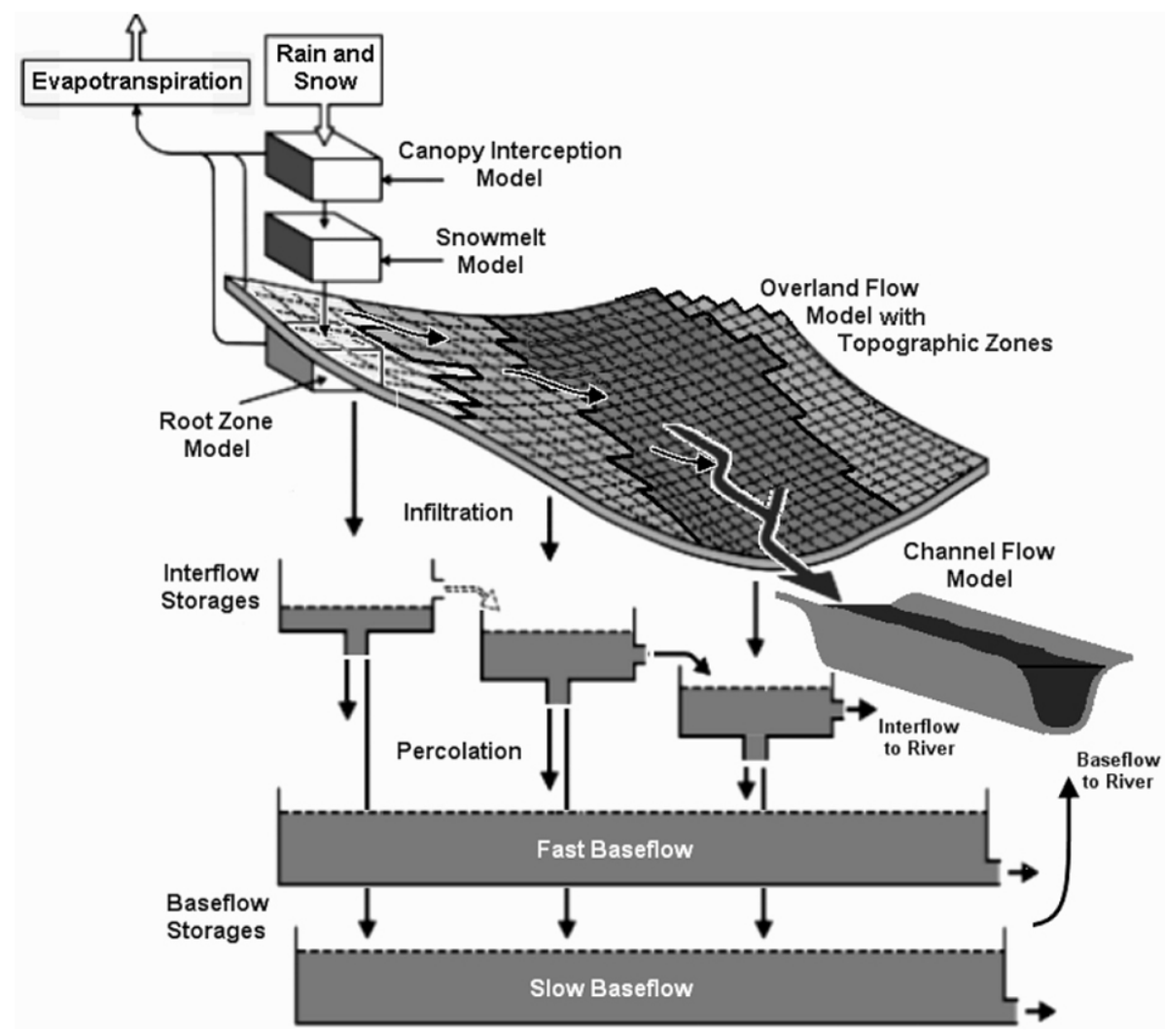

Fig. 4. Schematic representation of the applied MIKE SHE model configuration (Graham and Butts, 2006).

model configuration is schematized in Fig. 4 (Graham and Butts, 2006).

Hourly data from six rain gauges were used to describe the spatial variability of the rainfall over the catchment and used for meteorological input after applying Thiessen polygons. Only one potential evapotranspiration series was acquired from the national meteorological station located at Uccle, $30 \mathrm{~km}$ west of the study area, and applied. The growing cycle of the different crops was considered by means of a vegetation database that included leaf area index (LAI) and root depth (RD) and was based on Rubarenzya et al. (2007). Additional empirical parameters for determining the evapotranspiration of the crops were assessed from the literature (Kristensen and Jensen, 1975; DHI Water and Environment, 2008). The overland flow component was determined by the Strickler roughness coefficient, detention storage and initial water depths. The surface roughness was based on values from the literature (Chow, 1964) as a function of land use. Standard values were taken for the detention storage and initial water depths and are considered constant over the entire catchment (DHI Water and Environment, 2008). The MIKE SHE model was coupled to a full hydrodynamic river model, implemented in MIKE 11 (DHI Water and Environment, 2009) to route MIKE SHEs overland flow to the catchment outlet and account for the hydraulic effects of the river network and its infrastructure. The river network comprised the main branches in the catchment, which were extracted from the Flemish hydrological atlas (FEA, 2005). The geometry of each river branch was specified in terms of cross sections obtained from field survey data. All infrastructures that were expected to have a significant impact on the river flow, such as bridges, culverts and weirs, were implemented in the model. For the unsaturated soil water component of the catchment model, soil moisture characteristics were defined by means of the model by Brooks and Corey (1966) for soil retention curves, and the equation by Averjanov (1950) for the soil hydraulic conductivities. The unsaturated zone parameters, needed to identify these relations, were based on the USDA - United States Department of Agriculture soil information database. As mentioned above, the saturated zone was implemented through baseflow reservoirs applying simplified lumped storage and flow descriptions and parameters. More specifically, the entire groundwater system was divided into a series of shallow interflow reservoirs plus two deep baseflow reservoirs. These reservoirs allowed for differentiating between fast and slow components of baseflow discharge and storage. An overview of the most important model parameters in the considered model configuration is presented in Table 2.

Soil characteristics were derived from the USDA soil parameters classification system (Graham and Butts, 2006). Saturated zone flow was simulated using the linear reservoir 
Table 1. Overview of the different land use classes used in the NGI map and the reclassification to 9 categories.

\begin{tabular}{|c|c|}
\hline NGI description & IGBP vegetation \\
\hline Coniferous trees & Evergreen needleleaf forest \\
\hline Orchard & Evergreen needleleaf forest \\
\hline Tree nursery & Evergreen needleleaf forest \\
\hline Deciduous trees & Broad-leaved woodland \\
\hline Poplar plantation & Broad-leaved woodland \\
\hline $\begin{array}{l}\text { Mixed deciduous and } \\
\text { coniferous trees } \\
\text { without dominant }\end{array}$ & Mixed forest \\
\hline $\begin{array}{l}\text { Mixed deciduous and } \\
\text { coniferous trees } \\
\text { with dominance of } \\
\text { deciduous trees }\end{array}$ & Mixed forest \\
\hline $\begin{array}{l}\text { Mixed deciduous and } \\
\text { coniferous trees } \\
\text { with dominance of } \\
\text { coniferous trees }\end{array}$ & Mixed forest \\
\hline Sand & Open scrublands \\
\hline Bare ground & Open scrublands \\
\hline Coppice & Open scrublands \\
\hline Heath & Open scrublands \\
\hline Heath with deciduous trees & Open scrublands \\
\hline Heath with coniferous trees & Open scrublands \\
\hline Scrubs & Open scrublands \\
\hline Brushwood & Open scrublands \\
\hline Brushwood with scrubs & Open scrublands \\
\hline Cemetery & Grasslands \\
\hline Beds & Grasslands \\
\hline Pasture & Grasslands \\
\hline Gardens & Grasslands \\
\hline Deep swamp & Permanent wetlands \\
\hline Reedland & Permanent wetlands \\
\hline Cropland & Croplands \\
\hline Transformer station & Impervious area \\
\hline Railway & Impervious area \\
\hline Road & Impervious area \\
\hline Crossroad & Impervious area \\
\hline Industrial building (in use) & Impervious area \\
\hline Industrial building (abandoned) & Impervious area \\
\hline Warehouse & Impervious area \\
\hline Silo & Impervious area \\
\hline Greenhouse & Impervious area \\
\hline Cooling tower & Impervious area \\
\hline Non-university hospital & Impervious area \\
\hline Town hall & Impervious area \\
\hline Schoolhouse & Impervious area \\
\hline Firehouse & Impervious area \\
\hline Commercial building & Impervious area \\
\hline Religious building & Impervious area \\
\hline Sports hall & Impervious area \\
\hline Covered grandstand & Impervious area \\
\hline Non-covered grandstand & Impervious area \\
\hline Indoor swimming pool & Impervious area \\
\hline Building for drinking water supply & Impervious area \\
\hline Normal building & Impervious area \\
\hline Building for public use & Impervious area \\
\hline Watercourse & Water bodies \\
\hline Pond & Water bodies \\
\hline Sluice & Water bodies \\
\hline
\end{tabular}

method. The entire groundwater system was divided into a series of shallow interflow reservoirs plus two deep baseflow reservoirs. These reservoirs allowed for differentiating between fast and slow components of baseflow discharge and storage. Water was routed through the linear reservoirs as interflow and baseflow and subsequently added to the MIKE 11 river network as lateral inflow in the lowest interflow reservoir (Graham and Butts, 2006).

\subsection{Implementing the hydrological influence of the sewer infrastructure in MIKE SHE}

To model the effect of the EIA on the hydrological regime of the Grote Nete catchment, the detailed land use map $(1: 5000)$ and EIA had to be resampled to the MIKE SHE model grid specifications $(250 \mathrm{~m})$. Despite the careful resampling for preserving the catchment land use in the model, an overestimation of TIA by $4.2 \%$ remained. For each WWCR, the urban area and EIA were extracted and the percentage EIA per urban area WWCR calculated. These calculations were used in combination with the resampled urban area per WWCR in MIKE SHE to define the fraction of rainfall discharged by the sewer infrastructure to the river. Table 3 presents the percentage of EIA per WWCR and its urban area.

Incorporating the impact of the sewer infrastructure within the MIKE SHE model can be done in two different ways. This basically involves the removal of the surface runoff that is going to the sewer network from the total catchment runoff. This surface runoff to the sewage system can then be added to the river network at the WWTP discharge location as a point source, after accounting for the sewer WWTP routing time delay. To remove the sewer runoff from the catchment runoff, one of the first solutions is to take out, from the modeling domain, the grid cells that cover the impervious areas and that contribute to the sewer system. The problem encountered here in this study is that none of the $250 \mathrm{~m}$ grid cells are fully covered by that type of impervious surfaces. Only fractions of the grid cell areas contribute to the sewer system, making the removal of the grid cells impossible. Therefore we opted for the second solution: reducing the rainfall input proportional to the fraction of the sewer runoff contribution. This allowed us to take better in to account the fractions of impervious areas within each grid cell.

Three different rainfall scenarios were developed to assess the impact of the sewer system. For each scenario, the total measured rainfall in the catchment was reduced in relation to the assessed WWTP discharges. The rainfall reductions were spatially differentiated within the catchment by reducing the different rainfall series based on the overlap between the Thiessen polygons (different point rainfall input series) and the different WWCR regions (amount of EIA). The different scenarios of reduced rainfall were applied within the model to assess its impact in the model. Scenario 1 considered a reduction in rainfall within the WWCRs that discharge 
Table 2. Overview of the MIKE SHE model parameters in the considered model configuration.

\begin{tabular}{|c|c|c|c|}
\hline Component & Parameter & Description & Unit \\
\hline \multirow[t]{6}{*}{ Evaporation } & $C_{\text {int }}$ & Canopy interception & $\mathrm{mm}$ \\
\hline & $c 1, c 2, c 3$ & Evapotranspiration empirical parameters & $\mathrm{mm} \mathrm{day}^{-1}$ \\
\hline & $A_{\text {root }}$ & Root distribution index & $1 / \mathrm{m}$ \\
\hline & $K_{\mathrm{c}}$ & Crop coefficient & - \\
\hline & LAI & Leaf area index & - \\
\hline & RD & Root depth & $\mathrm{mm}$ \\
\hline \multirow[t]{3}{*}{ Overland flow } & $M$ & Strickler roughness coefficient & $\left(\mathrm{m}^{3} \mathrm{~s}^{-1}\right)-1$ \\
\hline & DS & Detention storage of the ground surface & $\mathrm{mm}$ \\
\hline & $H_{\text {ini }}$ OF & Initial water depth on the ground surface & $\mathrm{mm}$ \\
\hline \multirow[t]{6}{*}{ Unsaturated flow } & $\theta_{\text {sat }}$ & Saturated soil water content & $\mathrm{m}^{3} \mathrm{~m}^{-3}$ \\
\hline & $\theta_{\mathrm{FC}}$ & Soil water content at field capacity & $\mathrm{m}^{3} \mathrm{~m}^{-3}$ \\
\hline & $\theta_{\mathrm{WP}}$ & Soil water content at field wilting point & $\mathrm{m}^{3} \mathrm{~m}^{-3}$ \\
\hline & $\theta_{\text {res }}$ & Residual soil water content & $\mathrm{m}^{3} \mathrm{~m}^{-3}$ \\
\hline & $K_{\text {sat }}$ & Saturated hydraulic conductivity & $\mathrm{ms} \mathrm{s}^{-1}$ \\
\hline & $n$ & Averjanov empirical constant & - \\
\hline \multirow[t]{3}{*}{ Channel flow } & $H_{\text {ini_CF }}$ & Initial water level & $\mathrm{mm}$ \\
\hline & $Q_{\text {ini_CF }}$ & Initial discharge & $\mathrm{m}^{3} \mathrm{~s}^{-1}$ \\
\hline & $n$ & Bed resistance & $\left(\mathrm{m}^{3} \mathrm{~s}^{-1}\right)-1$ \\
\hline \multirow[t]{13}{*}{ Groundwater flow } & $S_{\mathrm{y} \_\mathrm{IF}}$ & Specific yield for interflow reservoir & - \\
\hline & $H_{\text {ini_IF }}$ & Initial depth of the interflow reservoir & $\mathrm{m}$ \\
\hline & $H_{\text {treshold_IF }}$ & Threshold depth of the interflow reservoir & $\mathrm{m}$ \\
\hline & $H_{\text {bottom_IF }}$ & Bottom depth of the interflow reservoir & $\mathrm{m}$ \\
\hline & $t_{\text {percolation }}$ & Percolation time & days \\
\hline & $R C_{\mathrm{IF}}$ & Interflow time constant & days \\
\hline & $\alpha_{\mathrm{SZ}}$ & Fraction of percolation to the baseflow reservoir & - \\
\hline & $S_{\mathrm{y} \_\mathrm{BF}}$ & Specific yield for the baseflow reservoir & - \\
\hline & $R C_{\mathrm{BF}}$ & Baseflow time constant & days \\
\hline & $\alpha_{\mathrm{UZ}}$ & Unsaturated zone feedback fraction for baseflow & - \\
\hline & $H_{\text {ini_BF }}$ & Initial depth of the baseflow reservoir & $\mathrm{m}$ \\
\hline & $H_{\text {treshold_BF }}$ & Threshold depth of the baseflow reservoir & $\mathrm{m}$ \\
\hline & $H_{\text {bottom_BF }}$ & Bottom depth of the baseflow reservoir & $\mathrm{m}$ \\
\hline
\end{tabular}

within the catchment to assess the impact of the sewer infrastructure on the river flows. Scenario 2 implemented a reduction in rainfall within the WWCRs that discharge outside the catchment to assess the impact of water transport outside the catchment. Scenario 3 took a reduction in rainfall across the entire catchment to evaluate the impact of all the sewers on the river system (Table 3 ). The original measured rainfall input series, applied to calibrate the model, is further referred to as the reference scenario.

The differences in runoff discharges between the initial model result and the simulations with reduced rainfall input gave us indications of the impact of the sewer infrastructure on the catchment runoff. The model results were compared for the different scenarios and assessed on an hourly, daily and monthly basis. The reductions in flow because of reduced rain were compared to the measured WWTP discharges as well as their relative contributions to the total river flows. Differences in relative contributions were calculated between the reference scenario and the rainfall scenarios 1 and 3 . Changes in peak and low flows were evaluated in relation to the empirical return period (mean recurrence interval of these flows).

\subsection{MIKE SHE model calibration}

After completing the model setup, the MIKE SHE model was calibrated. Note that the MIKE SHE model code comprises numerous free parameters, whereas the guiding principle for complex models like MIKE SHE is to calibrate the model on as few free parameters as possible (Refsgaard and Storm, 1995). Therefore, the calibration parameters were reduced by a parameter sensitivity analysis similar to Xevi et al. (1997) and Thompson et al. (2004). The results of this sensitivity analysis for the Grote Nete model are not presented here, but can be found in Vansteenkiste et al. (2013). They show that the most sensitive parameters are the surface roughness and saturated zone parameters. These parameters are mainly related to the groundwater computations, but also have a strong influence on both low-flow and peak-flow magnitudes. In the end the model was calibrated using 14 parameters per 
Table 3. Different variables used to implement the reduced rain scenarios: EIA in the catchment (ha), EIA per WWCR (\%) and EIA per urban area unit (\%) based on the NGI data.

\begin{tabular}{lrllccc}
\hline WWTP & $\begin{array}{r}\text { EIA (ha) } \\
\text { per WWCR }\end{array}$ & $\begin{array}{l}\text { EIA per } \\
\text { WWCR (\%) }\end{array}$ & $\begin{array}{l}\text { EIA per } \\
\text { urban area } \\
\text { WWCR (\%) }\end{array}$ & Scenario 1 & Scenario 2 & Scenario 3 \\
\hline Mol & 782.07 & 5.17 & 72.77 & $*$ & & $*$ \\
Geel & 284.31 & 7.2 & 67.42 & $*$ & & $*$ \\
Leopoldsburg & 32.04 & 6.99 & 48.5 & $*$ & & $*$ \\
Tessenderlo & 418.85 & 6.58 & 76.21 & & $*$ & $*$ \\
Westerlo & 182.96 & 4.77 & 67.22 & & $*$ & $*$ \\
Beverlo & 41.14 & 5.43 & 87.34 & & $*$ & $*$ \\
Lommel & 145.43 & 2.75 & 47.57 & & $*$ & $*$ \\
Eksel & 101.6 & 2.27 & 74.04 & & $*$ & $*$ \\
\hline
\end{tabular}

* indicates the WWRCs for which the rain was reduced in each scenario.

grid cell related to the distributed raster information, and 20 catchment-wide parameters related to the groundwater flow and evapotranspiration processes.

Calibration of the model was done against hourly stream flow measurements at the catchment outlet for the time period 2004-2006, while the years 2007 and 2008 were used for model validation. The most sensitive parameters were iteratively and manually adjusted between predefined limits until maximal correspondence between measured and predicted discharge runoff downstream of the catchment was achieved. The predefined parameter value limits represent the physically acceptable intervals and have been assessed on the basis of previous modeling studies of the Grote Nete catchment (Rubarenzya et al., 2007; Woldeamlak et al., 2007) and the literature (Chow et al., 1988; Anderson and Woessner, 1991; DHI Water and Environment, 2008).

The model correspondence was evaluated both qualitatively by visual inspection of the runoff results and quantitatively using goodness-of-fit statistics, including mean error (ME), root-mean-squared error (RMSE), correlation coefficient $(R)$ and Nash-Sutcliffe efficiency (NSE) (Nash and Sutcliffe, 1970). Because the aim of this study was to investigate the impact on both high and low river flow conditions, independent peak and low flows, extracted from the time series using the method of Willems (2009), were also explicitly validated. This was done in scatterplots of simulated versus observed values as well as by means of empirical frequency distributions (peak and low flows versus return periods). The return periods of peak and low flows were calculated empirically as the total length of the available time series (in years) over the peak- and low-flow rank (1 for highest, 2 for second highest, etc.). Box-Cox transformation was applied to the simulated and observed peak and low flows to reach homoscedastic model residuals (Willems, 2009). This means that the model residuals can be represented by one distribution and equal weight is given to the peak- and low-flow values. The RMSE of the model residuals after transformation was optimized during model calibration.

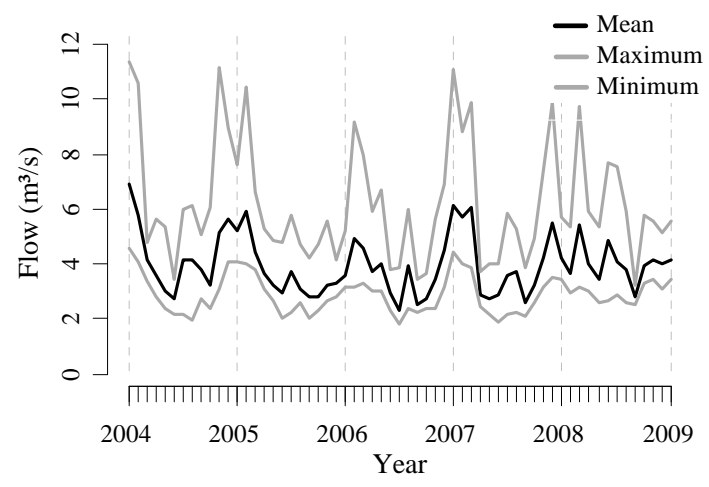

Fig. 5. Monthly mean, minimum and maximum of the daily measured flow $\left(\mathrm{m}^{3} \mathrm{~s}^{-1}\right)$ for the period 2004-2008 at the outlet station (Varendonk) of the Grote Nete catchment.

\section{Results}

\subsection{River flow contribution of WWTPs}

Between January 2004 and December 2008, the Grote Nete had an average observed discharge of $3.95 \mathrm{~m}^{3} \mathrm{~s}^{-1}$ at the catchment outlet. The upstream WWTPs discharged for the same period on average $0.31 \mathrm{~m}^{3} \mathrm{~s}^{-1}$ of wastewater to the Grote Nete, or $7.9 \%$ of the river flow. Discharges of both the river and WWTPs, however, varied substantially in time (Fig. 5). Rain events always lead to strong changes in river flow. For example, in 2007 there was a noticeable reduction in baseflow during spring and summer, followed by a strong increase during the winter period. In 2008 several rain periods led to a higher average flow during spring and summer. Monthly mean discharges of WWTPs and monthly mean river flows were found to be well correlated $\left(r^{2}=0.72\right.$, $p<0.001)$. Correlation between daily mean WWTP and daily mean river discharges was, however, lower $\left(r^{2}=0.60\right.$, $p<0.001)$. 


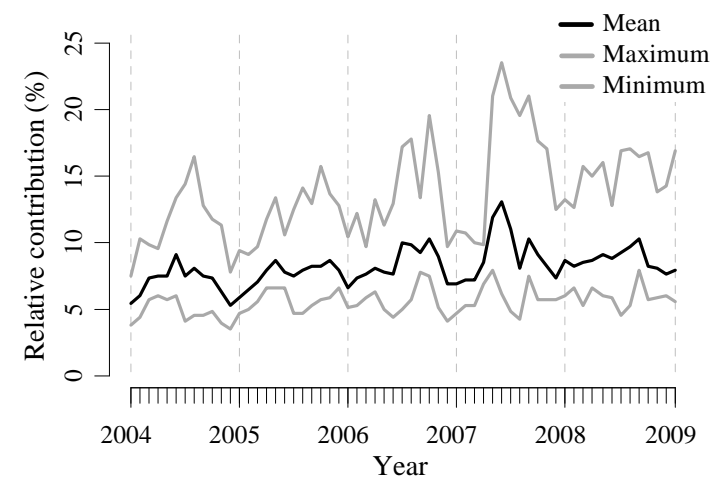

Fig. 6. Monthly mean, minimum and maximum relative contribution of the WWTPs (Mol and Geel) to the river flow at the outlet station (Varendonk) of the Grote Nete catchment.

In general, the WWTPs were found to contribute between 5.5 and $13.1 \%$ of the monthly average river flow at the Grote Nete catchment outlet (Fig. 6). On a daily basis the contribution of the WWTPs to the river flow can decrease to $5.5 \%$ during wet periods or increase up to $23.6 \%$ during dry summer periods. The highest relative contributions were observed for rain events that occur during low river flow periods (e.g., convective thunderstorm periods after long, dry summer periods).

\subsection{Water transfers between catchments and subcatchments}

\subsubsection{Current situation}

From the analysis of the WWCRs we conclude that there are significant water transfers between the Grote Nete catchment and adjacent catchments. Of the total of 2836 ha TIA in the catchment, 1661 ha are currently connected to the WWTPs. This gives an initial ratio of 0.6 between TIA and EIA. Only $54.0 \%$ of the EIA drains water that remains inside the catchment, the rest, mostly situated in the southern part of the catchment, drains water outside the catchment. At the same time waste-, ground- and rainwater from 461 ha, mostly from the north, is transported from outside to inside the catchment. If the difference in boundaries between catchment and WWCRs is taken into account, the EIA for the catchment is considered to be $1361 \mathrm{ha}$. This represents $4.0 \%$ of the entire catchment area.

Upstream impervious areas and total upstream area change substantially when the WWCRs are incorporated into the calculations. A comparison between both calculation methods for 131 river junctions illustrates this impact. By taking the WWCRs into account, total upstream impervious areas decrease up to $99 \%$, as for most subcatchments impervious areas are connected to a WWTP located outside the subcatchment. For other river junctions, the upstream areas increase up to $64 \%$ because a WWTP is situated upstream of the
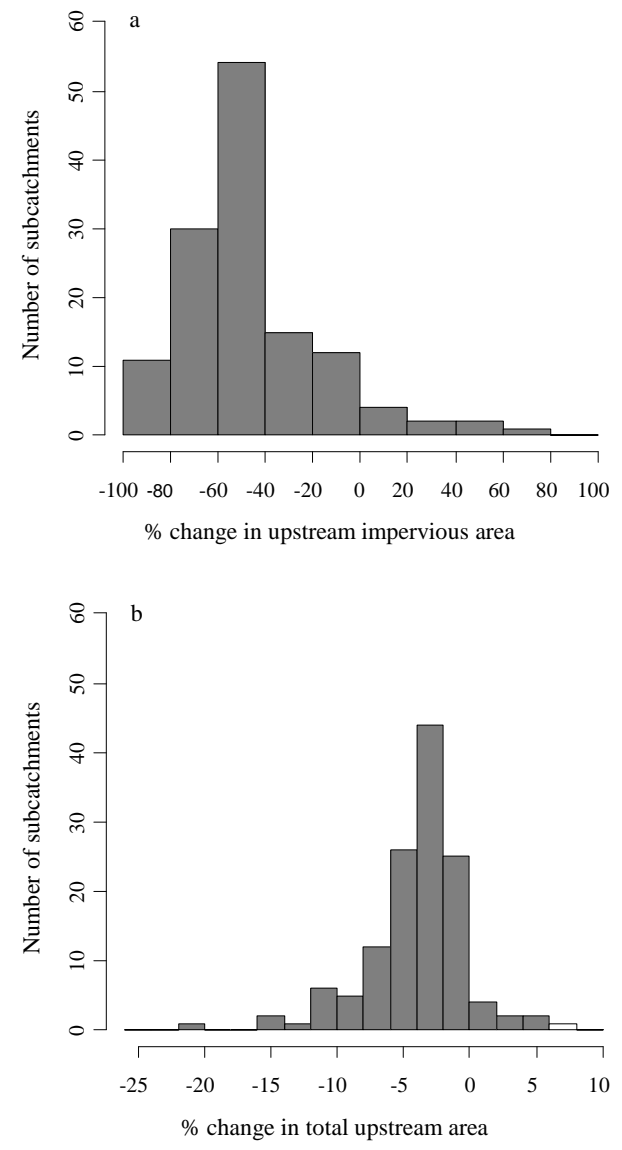

Fig. 7. (a) Histogram of the change in upstream impervious areas that demonstrates the impact of the sewer system on both upstream area calculations. For different stream junction points $(n=131)$ in the catchment, upstream impervious areas were calculated based on the natural catchment and after taking the sewer system into account. Differences between both types of upstream impervious areas were calculated as percentage change for each junction. (b) Histogram of the change in total upstream areas that demonstrates the impact of the sewer system on both upstream area calculations. For different stream junction points $(n=131)$ in the catchment, total upstream areas were calculated based on the natural catchment and after taking the sewer system into account. Differences between both types total upstream areas were calculated as percentage change for each junction.

junction (Fig. 7a). For the same reason, the change in total upstream area varies strongly (Fig. 7b).

\subsubsection{Future developments}

When the WWCR zoning plans are fully implemented in the future, another 245 ha of impervious areas will be connected to the WWTPs. Of those 245 ha, the surface runoff of 141 ha will be transported to other catchments, while the surface runoff of 148 ha will be imported from neighboring catchments. 
Table 4. MIKE SHE calibrated parameters for the saturated zone.

\begin{tabular}{llll}
\hline & $\begin{array}{l}\text { Interflow } \\
\text { reservoir }\end{array}$ & $\begin{array}{l}\text { Baseflow } \\
\text { reservoir 1 }\end{array}$ & $\begin{array}{l}\text { Baseflow } \\
\text { reservoir 2 }\end{array}$ \\
\hline Specific yield [-] & 0.22 & 0.2 & 0.2 \\
Initial depth [m] & 15 & 30 & 30 \\
Bottom depth [m] & 15.065 & 40 & 40 \\
Threshold depth [m] & 15 & 30 & 30 \\
Time constant [days] & 4 & 12 & 12 \\
Percolation time constant [days] & 1.5 & - & - \\
Fraction of percolation [-] & 0.82 & - & - \\
UZ feedback fraction [-] & - & 0.32 & 0.12 \\
\hline
\end{tabular}

When all subcatchments are evaluated, it is seen that most of the river junctions will experience an extra reduction in upstream area by 1 or $2 \%$ (Fig. 8). Ten river junctions will, however, experience an increase of their upstream area by 1 or $2 \%$ because of the upstream presence of a WWTP.

\subsection{Model calibration and validation results}

In comparison with Vansteenkiste et al. (2013) the main difference in the parameterization of the MIKE SHE model was related to the saturated zone component (Table 4) and the fine tuning of the overland flow roughness parameters (Table 5). Other parameters related to the overland flow, river flow and unsaturated zone were identical to Vansteenkiste et al. (2013).

Table 6 shows the model performance statistics ME, RMSE, $R$ and NSE. These demonstrate the good general model performance. The statistics, however, demonstrate that the model performance is slightly better in the calibration period than in the validation period. Figure 9 shows the observed and simulated hourly runoff series for the calibration period.

Additional verification of the model performance for the high- and low-flow extremes is presented in Fig. 10. The observed independent high- and low-flow extremes are plotted against the simulated ones after Box-Cox transformation. These validation plots allow for evaluation of the model for its ability to predict extreme conditions. The model is able to simulate the extreme peak flows well, while the low-flow extremes are slightly overestimated by the model. The ME is very small for the peak flows $\left(0.05 \mathrm{~m}^{3} \mathrm{~s}^{-1}\right)$ and larger for the independent low-flow extremes $\left(0.14 \mathrm{~m}^{3} \mathrm{~s}^{-1}\right)$. Based on the good general model performance for total flows in both calibration and validation periods and for peak flows, the model was considered applicable for assessing the impact of the water transfers on these flow variables as a result of the sewer infrastructure.
Table 5. MIKE SHE calibrated parameters for the surface.

\begin{tabular}{ll}
\hline & $\begin{array}{l}\text { Strickler } \\
\text { roughness } \\
\text { coefficient } \\
{\left[\mathrm{m}^{1 / 3} \mathrm{~s}^{-1}\right]}\end{array}$ \\
\hline Deciduous needleleaf forest & 2.5 \\
Deciduous broadleaf forest & 1.25 \\
Mixed forest & 1.82 \\
Grasslands & 6 \\
Permanent wetlands & 2 \\
Croplands & 13 \\
Urban and built-up & 90 \\
Water bodies & 90 \\
\hline
\end{tabular}

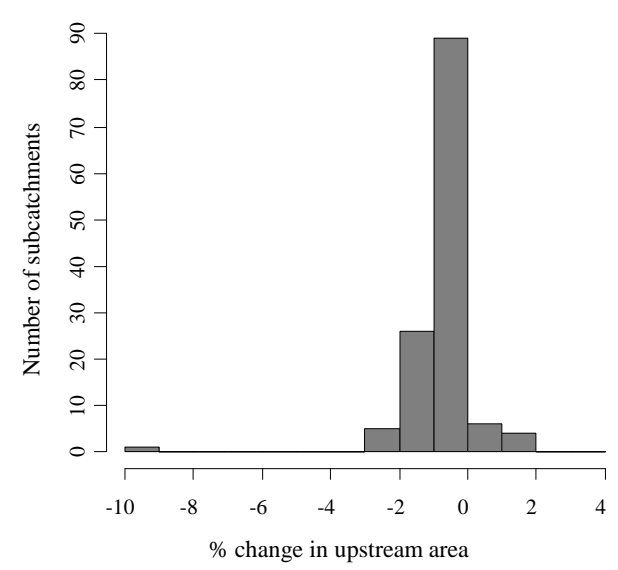

Fig. 8. Histogram of the change in upstream areas after full implementation of the zoning plans. For different stream junction points $(n=131)$ in the catchment, total upstream areas were calculated by comparing the current sewer system and the future sewer system after full implementation of the zoning plans. Differences in total upstream areas are given as percentage change for each stream junction.

\subsection{Comparison with model impact results}

\subsubsection{River flow impact of WWTPs}

As a first step, the different rainfall scenarios are compared with the reference scenario. Figure 11 shows the modelbased differences in mean monthly river flows between the reference scenario and the adjusted rainfall scenarios. Based on this difference, the relative contributions of the EIA to the total river flow were obtained. These relative contributions vary between 2.2 and $7.2 \%$ for scenario 1 . For scenario 2 these contributions vary between 2.8 and $6.1 \%$.

\subsubsection{Seasonal variation in river flow impact}

A seasonal change in relative contribution of the WWTP infrastructure to the river flow was found. The largest contributions to the overall flow were found during summer and 
Table 6. Statistical performance of total hourly river flows for the model calibration and validation periods at the outlet station of the Grote Nete catchment.

\begin{tabular}{llc}
\hline & Calibration & Validation \\
\hline $\mathrm{ME}\left[\mathrm{m}^{3} \mathrm{~s}^{-1}\right]$ & 0.6 & 0.72 \\
$\mathrm{RMSE}\left[\mathrm{m}^{3} \mathrm{~s}^{-1}\right]$ & 0.84 & 0.93 \\
$R[-]$ & 0.88 & 0.84 \\
$\mathrm{NSE}[-]$ & 0.72 & 0.63 \\
\hline
\end{tabular}

lowest during winter periods. The effect is, however, again less pronounced compared to the relative contribution based on the empirical analysis (Fig. 11).

A comparison is made between the model-based impact results and the empirical analysis of Sect. 3.1, where the river flows at the outlet station are adjusted for the connected areas. Results of that comparison show strong seasonal patterns in differences between the model-based and empirical analysis results (Fig. 12). Especially during the period of declining flows (flow recession periods) in spring and the beginning of summer, the model simulates much lower relative contributions of WWTP discharges compared to the empirical analysis. This difference is less pronounced or absent for the summer of 2008.

\subsubsection{Impact on peak and low flows}

The model-based impact results of the scenarios result in a decrease of both peak (Fig. 13a) and low flows (Fig. 13b) for given return periods. For events with an empirical return period higher than 1 year, both peak and low flows decrease proportional to the reduced rain scenarios. The effects thus are stronger for the low-flow event compared to the peak flow events (Table 7).

\section{Discussion}

\subsection{Impact of WWTPs on the river baseflow}

The overall impact of the WWTPs on the river flow depends on the timescale (daily, monthly or yearly). On average, the WWTPs are responsible for about $10 \%$ of the catchment's discharge, but the relative WWTP contributions to the river flow can be significantly higher at short timescales and during dry periods (Fig. 6). The sewer infrastructure in the catchment is hence found to be an important point source of water in the rivers.

The high WWTPs effluent contribution to the total mean river discharge is due to the combined effect of different sewer-infrastructure-related processes: wastewater collection, rainwater runoff and groundwater intrusion. That parasitic groundwater, due to the groundwater intrusion, can be high in the region as has also been shown before by Dirckx
Table 7. Absolute and relative changes in peak and low flows at the outlet station of the Grote Nete catchment for empirical return periods higher than 1 year and the different rainfall scenarios compared with the reference scenario.

\begin{tabular}{llllll}
\hline & \multicolumn{2}{c}{ Peak flows } & & \multicolumn{2}{c}{ Low flows } \\
\cline { 2 - 3 } \cline { 5 - 6 } & $\mathrm{m}^{3} \mathrm{~s}^{-1}$ & $\%$ & & $\mathrm{~m}^{3} \mathrm{~s}^{-1}$ & $\%$ \\
\hline Scenario 1 & 0.33 & 3 & & 0.3 & 5.5 \\
Scenario 2 & 0.3 & 2.8 & & 0.11 & 4.9 \\
Scenario 3 & 0.62 & 6 & & 0.23 & 10.6 \\
\hline
\end{tabular}

et al. (2009). Due to this draining of the groundwater table, drought-related problems induced by the urbanization will further increase. Climate change scenarios for Flanders predict a strong decrease in river low flows during summer (Baguis et al., 2010; Vansteenkiste et al., 2013). The impact of the WWTPs on the overall flow is thus expected to increase in the future.

While the impact of the WWTPs on a river flow can be evaluated rather easily, the impact of connected impervious area on the flow regime of smaller reaches within the WWCR is more difficult to quantify. Often the roofs of buildings and pavements of a catchment are connected to sewers that transport storm and wastewater to a WWTP, which might be located outside the natural catchment boundary. If we would like to evaluate these changes, long-term river flow data need to be available that encompass also river flow data prior to the sewer development. Also a detailed inventory of the gradual expansion of the sewer infrastructure would be required.

\subsection{TIA versus EIA}

Impervious area is a landscape metric that is widely used as an indicator of water quality, quantity and river ecosystem health (Jacobson, 2011). In the empirical analysis, conducted in this study, the impact of the sewer infrastructure on the impervious areas within the catchment was evaluated. The proposed method allowed us to make a distinction between TIA and EIA and to evaluate both transfers between catchments and subcatchments. Whereas both upstream TIA and EIA were found to be useful indicators of the hydrological and ecological disturbance, the EIA is in general considered to be a better indicator for the anthropogenic impact on the hydrological regime (Roy and Shuster, 2009). The EIA of the catchment decreased significantly when the different WWCRs were incorporated into the calculation. Large parts of the connected impervious areas within the catchment do not contribute to the river flows inside the catchment but are drained to a neighboring catchment. As a result, the overall impact of urbanization within the catchment can be over- or underestimated. At the same time large amounts of wastewater are transported from outside the catchment. These changes to the natural system affect both 


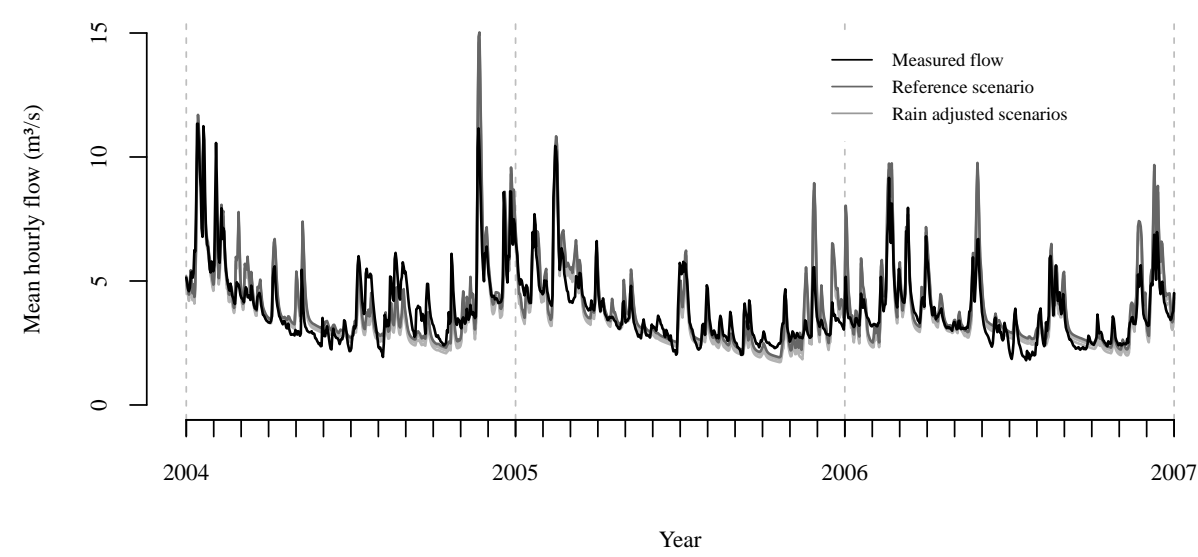

Fig. 9. Observed and simulated hourly river flow series for the model calibration period on a daily time step.
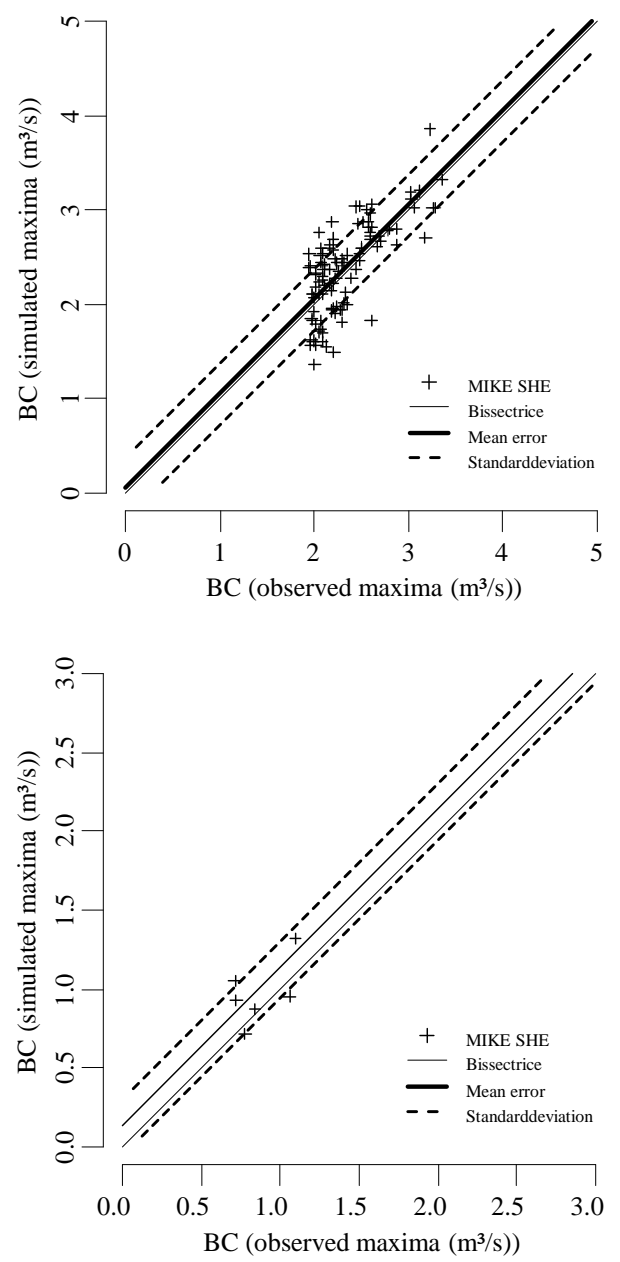

Fig. 10. (a) Scatter plot of simulated versus observed independent hourly peak flows at the outlet station of the Grote Nete catchment after Box-Cox transformation $(\lambda=\dot{0} \cdot 25)$. (b) Scatter plot of simulated versus observed independent hourly low flows at the outlet station of the Grote Nete catchment after Box-Cox transformation $(\lambda=0.25)$.

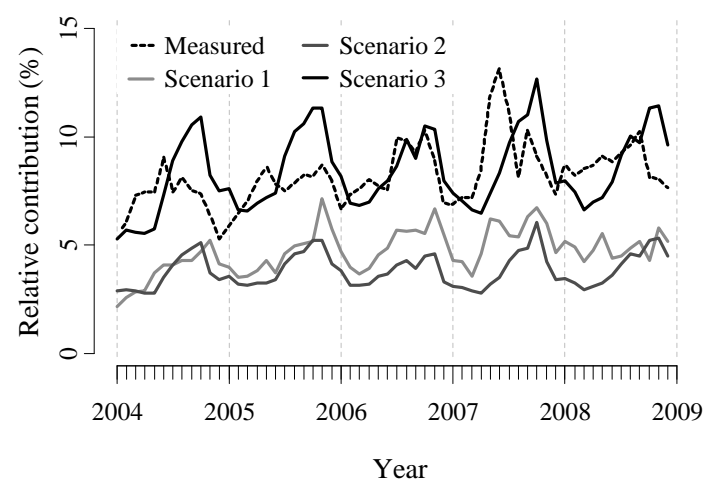

Fig. 11. Relative contribution (\% monthly mean total flow) of the WWTPs to the total river flow. Measured refers to the empirical results obtained in Sect. 3.1.

the spatial and temporal distribution of runoff water in the catchments: from spatially distributed runoff to point inflows, from one catchment to another, increased surface runoff, reduced groundwater infiltration, shorter travel time and hence higher temporal and spatial aggregation, etc.

The changes in the total upstream areas, between -16 and $+3 \%$, and upstream impervious areas, between -99 and $+64 \%$, in our study were found to be large. For most of the subcatchments in our research area, both total upstream area and upstream impervious area decreased significantly. Although these subcatchments do not have actual upstream EIA, they are affected by the reduction in upstream impervious areas and the resulting decreased total upstream area. These reductions in impervious areas and the transfer of storm and wastewater to other reaches can lead to reductions in the flow regime and changes in related river characteristics. The actual absence of upstream impervious areas, due to wastewater allocation, might be more important than the presence of only a small portion of upstream impervious area. 


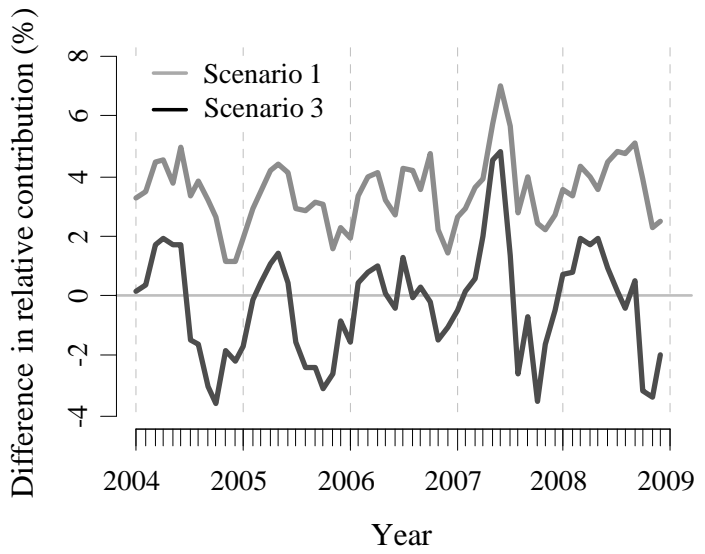

Fig. 12. Difference in relative contribution of the WWTPs to the total river flow at the outlet station of the Grote Nete catchment (\% difference in monthly mean total flow) between the model-based and empirical analysis results (rainfall scenario 1 and 3). The difference in contribution increases during flow recession periods.

In contrast to many other studies we were able to use highresolution data that are based on manual field observations instead of less accurate remote sensing data. The use of proxies for impervious areas, as used in other studies (Chabaeva et al., 2009), was not necessary. The same counts for the calculation of the EIA. Despite the high resolution of the data, some uncertainties remain in the impervious area classification (e.g., use of NGI classes and its influence on the TIA calculation) and EIA calculation (e.g., actual connection between road surfaces and the underlying sewer system). However, we expect that both metrics, TIA and EIA, are close to the actual situation in 2008 during low-flow periods. Nevertheless, due to increasing urbanization and sewer development, both indicators require a regular update.

SODs can have a profound impact on the hydrology, especially during extreme rain events. But their responses to these rain events can vary widely and are difficult to predict. Although relevant to the study area, the available data were not sufficient to incorporate SODs into the river flow analysis or into the EIA calculations or model development. It is expected that incorporating SODs in the analysis would result in a reduction of the EIA during extreme rain events. If such extreme rain events were to be analyzed explicitly, SODs should be integrated in the EIA calculations.

\subsection{Model impact results}

As opposed to the empirical analysis, the model-based results allow for explicit consideration of the catchment runoff dynamics, the highly non-linear hydrological responses to the changes in impervious areas and the interactions between different runoff components. However the use of hydrological models has, as is the case for all models, limitations. Traditional hydrological models impose restrictions on how to
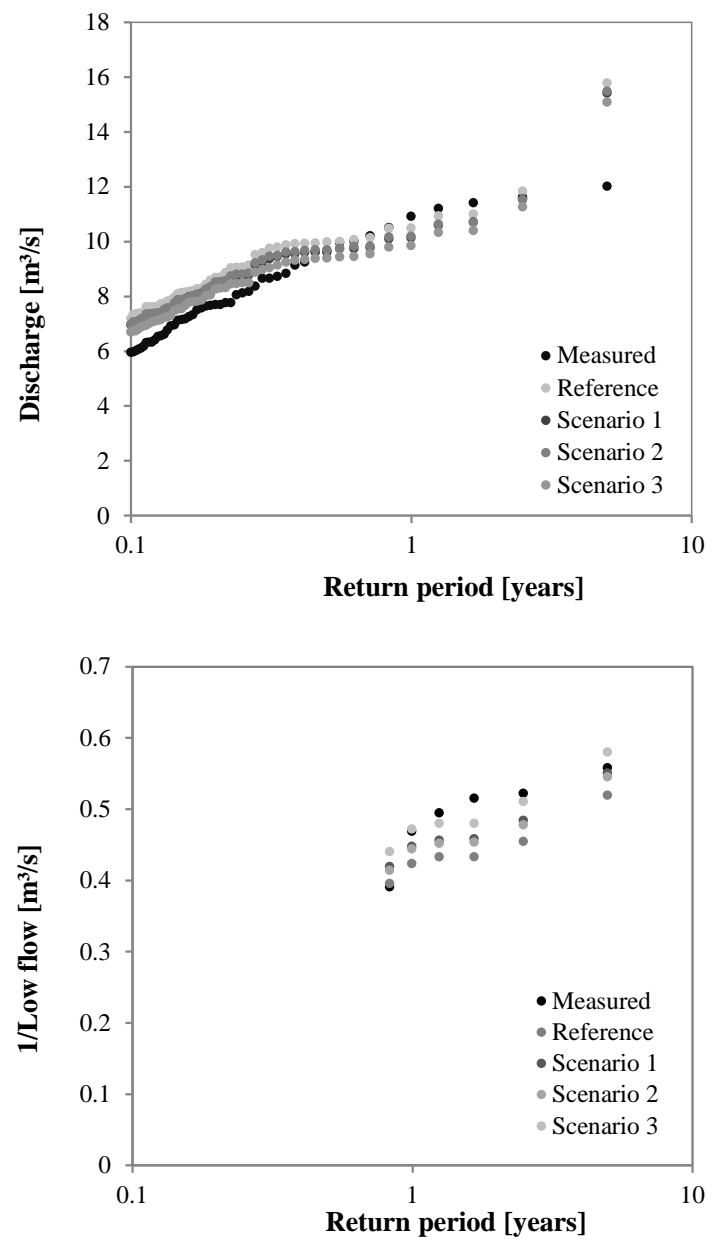

Fig. 13. (a) Return period of hourly peak flow extremes for the Grote Nete catchment between 2004 and 2008. (b) Return period of hourly low flow extremes for the Grote Nete catchment between 2004 and 2008.

deal with sewer infrastructure. In this study we evaluated the impact of the WWTPs by means of an existing, calibrated MIKE SHE hydrological model. Rainfall series were reduced proportional to the EIAs within the catchment to enable simulation of the impact of the surface runoff from impervious areas to the sewer system. This method is an alternative to the actual integration of a sewer model in the catchment model, which was not possible for reasons of data availability and model characteristics. Despite these simplifications of reality, the consistencies between the empirical and model-based results gave us confidence in the impact results. However, using this method it is not possible to evaluate the impact of the EIA situated outside the catchment. The latter impact evaluation would require sewer models to be integrated with the catchment hydrological model.

Previous studies have demonstrated the difficulties models can have to describe base flows in (peri-)urbanized areas (Elliott et al., 2010). Our model results revealed overestimations of low flow, while other recent studies have reported 
underestimations (Furusho et al., 2013). Hydrology in periurban catchments is typically a combination of fast and slow hydrological responses (Braud and Andrieu, 2013). The specific weighing of both responses is in general case specific and a result of the historical developments in the anthropogenic system. Although some characteristics in our catchment (e.g., fragmented land uses and related sewer system) are specific for the region, interbasin transfers of waste- and storm water are not rare and can play an important role at different scales in many peri-urban catchments. Impacts of these transfers in peri-urban catchments should therefore be analyzed and if necessary incorporated during model development. Bach and Ostrowski (2013) concluded, based on a semi-distributed model, that the representation of the flow processes in peri-urban models should take place at a high temporal and spatial resolution. Although FDPMs give a spatially detailed description of the hydrological processes, our results illustrate the challenges for sewer system integration in FDPMs, though they might be less if an open-source modeling system were used.

As expected, the different scenarios resulted in a decreased flow, compared to the reference scenario, proportional to the amount of EIA taken into account. The scenario with the lowest amount of EIA (scenario 2: transportation outside the catchment) resulted in the smallest change in flow. Besides an overall decrease in flow, both peak and low flows decreased. But low flows were proportionally more heavily affected by the rainfall reduction scenarios. These results confirm the higher impact of EIA during summer low flows found by the empirical analysis and again illustrate the high impact of EIA on the flow regime and its importance to be considered in the model. After consideration of the rainfall scenarios, the modeled rivers were higher than the measured river flow adjusted for the EIA, this despite the fact that the rainfall input was reduced for a similar amount within the different scenarios. Apparently, other processes like evapotranspiration within the model compensate for the reduced rainfall, leading to a lower reduction in flow.

Another problem is the coarse spatial resolution of the model. Due to this resolution, there is a general overestimation of both TIA and EIA implemented in the model compared to the high-resolution data. Nevertheless, similar values were obtained for the WWTP discharges and the reduction in flow in scenario 3 (full reduction based on all WWTPs). Because of the overestimation in the actual TIA and EIA, similar errors might be made to when no distinction is made between EIA and TIA (Alley and Veenhuis, 1983). At the same time the overestimation of the impervious surfaces may have biased the hydrological model parameters during the calibration (e.g., underestimation of the surface runoff coefficient). This means that if the model were to be used for impact analysis of urbanization and climate change scenarios, the impacts on peak flows and flood frequencies may be underestimated. This problem is further investigated by Vansteenkiste et al. (2013) for the MIKE SHE model of the same catchment considered in this study.

An important aspect is the seasonal variation in the relative contribution of the EIA compared to the empirical data. Both scenario 1 (reduction for WWTPs inside the catchment) and 3 (full reduction based on all WWTPs) resulted in an underestimation of the EIA impact on the river flow during months with low flow and an overestimation during months with high flow. Hydrological models are often used to evaluate peak discharges and related flood risks. Climate change scenarios for Flanders, however, indicate an increase in frequency and duration of dry periods, making low-flow events more common (Boukhris et al., 2009). Therefore the importance of these low-flow events and their evaluation in hydrological models will become more important. A better incorporation of both impervious areas and WWTPs might be crucial for a better performance of the models in evaluating the effect of climate change on peak and low-flow events. Hydrological models are frequently used to predict changes in the hydrological regime. But if we want to use these to assess changes in climate, land use or other future developments within the catchment, consideration of the sewer transfers discussed in this paper becomes increasingly important. Our results show that the further development of the sewer infrastructure will have a profound impact on the upstream areas.

\section{Conclusions}

This paper presented a methodology to calculate EIA in a way that incorporates the effects of WWCRs that do not coincide with natural catchment boundaries. The methodology allows us to evaluate storm- and wastewater transfers between different catchments and indicate how strongly the catchment's hydrology is impacted by the sewer infrastructure. Comparisons between histograms or differences in histograms of catchment areas can display the vulnerability of the catchments to impervious area impacts and potential peak and low-flow events. The method also allows for study of how rivers that have no WWTP upstream are impacted by the upstream presence of EIA. These upstream impervious areas can have profound impacts on infiltration, surface runoff and the river flow regime.

We also simulated the impacts of the changes in impervious areas and WWTPs in FDPMs. By applying different rainfall scenarios, the impacts of wastewater transfers in the catchment were simulated and evaluated. At the same time, we were able analyze the impervious area parameterization within the model. Our results show that water displacements in and between catchments may severely impact the hydrological model results. Hence it may also be important to take these displacements into account in the hydrological model development. Although we used high-resolution data, the limited integration of all sewer processes (e.g., SODs) in the 
analysis prevented us from completely assessing the impact of the sewer system on the model performance.

The correct incorporation of impervious areas in models is of utmost importance as impervious areas have an impact on catchment delineation and different aspects of the flow regime. With increasing urbanization and sewer development, the impact of these processes on the hydrological regime are expected to further increase in the future. Important areas of further research remain, amongst others, as to (a) how to incorporate impervious areas from outside the catchment into the model, (b) how to remove the areas that are transported outside the catchment from the model domain, (c) how to better represent the seasonal variation in impervious area and WWTP impact in the model, and (d) how to integrate these processes based on less detailed data sets.

Acknowledgements. This research was supported by the University of Antwerp (UA-BOF fund), the Flanders Hydraulics Research (Waterbouwkundig Laboratorium, division of the Authorities of Flanders) and the Belgian Federal Science Policy Office (SUDEM-CLI cluster project, program "Science for a Sustainable Development").

Edited by: T. Kjeldsen

\section{References}

Abbott, M. B. and Refsgaard, J. C.: Distributed Hydrological Modelling, 1st Edn., Kluwer Academic Publishers, Dordrecht, 1996.

Abbott, M. B., Bathurst, J. C., Cunge, J. A., O'Connell, P. E., and Rasmussen, J.: An introduction to the European Hydrological System - Systeme Hydrologique Europeen, "SHE", 1: History and philosophy of a physically-based, distributed modelling system, J. Hydrol., 87, 45-59, 1986.

Ajami, N. K., Gupta, H., Wagener, T., and Sorooshian, S.: Calibration of a semi-distributed hydrologic model for streamflow estimation along a river system, J. Hydrol., 298, 112-135, 2004.

Alley, W. M. and Veenhuis, J. E.: Effective impervious area in urban runoff modeling, J. Hydraul. Eng.-ASCE, 109, 313-319, 1983.

Anderson, M. P. and Woessner, W. W.: Applied Groundwater Modeling: Simulation of Flow and Advective Transport, 1st Edn., Academic Press, Dordrecht, 1991.

Arnold, C. L. and Gibbons, C. J.: Impervious surface coverage The emergence of a key environmental indicator, J. Am. Plan. Assoc., 62, 243-258, 1996.

Averjanov, S.: About permeability of subsurface soils in case of complete saturation, Engl. Collect., 7, 243-258, 1950.

Bach, M. and Ostrowski, M.: Analysis of intensively used catchments based on integrated modelling, J. Hydrol., 485, 148-161, 2013.

Baguis, P., Roulin, E., Willems, P., and Ntegeka, V.: Climate change scenarios for precipitation and potential evapotranspiration over central Belgium, Theor. Appl. Climatol., 99, 273-286, 2010.

Baker, D. B., Richards, R. P., Loftus, T. T., and Kramer, J. W.: A new flashiness index: Characteristics and applications to midwestern rivers and streams, J. Am. Water Resour. Assoc., 40, 503-522, 2004.
Becker, A. and Braun, P.: Disaggregation, aggregation and spatial scaling in hydrological, J. Hydrol., 217, 239-252, 1999.

Beven, K.: Changing ideas in hydrology - The case of physicallybased models, J. Hydrol., 105, 157-172, 1989.

Boukhris, O. E. F., Willems, P., and Vanneuville, W.: Water and Urban Development Paradigms: Towards an Integration of Engineering, Design and Management Approaches, chap. The impact of climate change on the hydrology in highly urbanised Belgian areas, CRC Press, Boca Raton, 271-276, 2009.

Boyd, M. J., Bufill, M. C., and Knee, R. M.: Predicting pervious and impervious storm runoff from urban drainage basins, Hydrological Sciences Journal - Journal Des Sciences Hydrologiques, 39, 321-332, 1994.

Boyle, D. P., Gupta, H. V., Sorooshian, S., Koren, V., Zhang, Z. Y., and Smith, M.: Toward improved streamflow forecasts: Value of semidistributed modeling, Water Resour. Res., 37, 2749-2759, 2001.

Brabec, E. A.: Imperviousness and Land-Use Policy: Toward an Effective Approach to Watershed Planning, J. Hydrol. Eng., 14, 425-433, 2009.

Brandes, D., Cavallo, G. J., and Nilson, M. L.: Base flow trends in urbanizing watersheds of the Delaware River basin, J. Am. Water Resour. Assoc., 41, 1377-1391, 2005.

Braud, I. andFletcher, T. D. and Andrieu, H.: Hydrology of periurban catchments: Processes and modelling, J. Hydrol., 485, 1-4, 2013.

Brooks, R. H. and Corey, A. T.: Properties of porous media affecting fluid flow, J. Irrig. Drain. Eng., 92, 61-68, 1966.

Carpenter, T. M. and Georgakakos, K. P.: Intercomparison of lumped versus distributed hydrologic model ensemble simulations on operational forecast scales, J. Hydrol., 329, 174-185, 2006.

Chabaeva, A., Civco, D. L., and Hurd, J. D.: Assessment of Impervious Surface Estimation Techniques, J. Hydrol. Eng., 14, 377387, 2009.

Chow, V. T.: Handbook of Applied Hydrology, McGraw-Hill Company, 1st Edn., New York, 1964.

Chow, V. T., Maidment, D. R., and Mays, L. W.: Applied Hydrology, 1st Edn., Tata McGraw-Hill Education, Singapore, 1988.

DHI Water and Environment: MIKE SHE user guide, DHI Software, Hørsholm, 2008.

DHI Water and Environment: MIKE11, a modeling system for rivers and channels, Reference Manual, DHI Software, Hørsholm, 2009.

Dirckx, G., Bixio, D., Thoeye, C., De Gueldre, G., and Van De Steene, B.: Dilution of sewage in Flanders mapped with mathematical and tracer methods, Urban Water J., 6, 81-92, 2009.

Elliott, A., Spigel, R., Jowett, I., Shankar, S., and Ibbitt, R.: Model application to assess effects of urbanisation and distributed flow controls on erosion potential and baseflow hydraulic habitat, Urban Water J., 7, 91-107, 2010.

ESRI Inc.: ArcGIS 9.3, ESRI Inc., Redlands, 2009.

FEA: Flemish Hygrological Atlas, Vlaamse Milieumaatschappij afdeling Operationeel Waterbeheer, Brussel, 2005.

FEA: Digital Elevation Model Flanders, raster, $5 \mathrm{~m}$, Agentschap voor Geografische Informatie Vlaanderen, Gent, 2006.

FEA: Sewer infrastructure of Flanders, Vlaamse Milieumaatschappij, Aalst, 2008a. 
FEA: Zoning Map of Flanders, Vlaamse Milieumaatschappij, Aalst, 2008b.

Feyen, L., Vázquez, R., Christiaens, K., Sels, O., and Feyen, J.: Application of a distributed physically-based hydrological model to a medium size catchment, Hydrol. Earth Syst. Sci., 4, 47-63, doi:10.5194/hess-4-47-2000, 2000.

Furusho, C., Chancibault, K., and Andrieu, H.: Adapting the coupled hydrological model ISBA-TOPMODEL to the long-term hydrological cycles of suburban rivers: Evaluation and sensitivity analysis, J. Hydrol., 485, 139-147, 2013.

Graham, D. and Butts, M. B.: Watershed Models, chap. Flexible, integrated watershed modelling with MIKE SHE, 1st Edn., CRC Press, 245-272, 2006.

Hamel, P., Daly, E., and Fletcher, T. D.: Source-control stormwater management for mitigating the impacts of urbanisation on baseflow: A review, J. Hydrol., 485, 201-211, 2013.

Jacobson, C. R.: Identification and quantification of the hydrological impacts of imperviousness in urban catchments: A review, J. Environ. Manage., 92, 1438-1448, 2011.

Jakeman, A. J. and Letcher, R. A.: Integrated assessment and modelling: features, principles and examples for catchment management, Environ. Model. Softw., 18, 491-501, 2003.

Jankowfsky, S., Branger, F., Braud, I., Gironás, J., , and Rodriguez, F.: Comparison of catchment and network delineation approaches in complex suburban environments: application to the Chaudanne catchment, France, Hydrol. Process., 27, 3747 3761, doi:10.1002/hyp.9506, 2013.

Jenson, S. K. and Domingue, J. O.: Extracting topographic structure from digital elevation data for geographic information system analysis, Photogrammetric Engineering and Remote Sensing, 54, 1593-1600, 1988.

Kauffman, G. J., Belden, A. C., Vonck, K. J., and Homsey, A. R.: Link between Impervious Cover and Base Flow in the White Clay Creek Wild and Scenic Watershed in Delaware, J. Hydrol. Eng., 14, 324-334, 2009.

Kleidorfer, M., Deletic, A., Fletcher, T. D., and Rauch, W.: Impact of input data uncertainties on urban stormwater model parameters, Water Sci. Technol., 60, 1545-1554, 2009.

Kristensen, K. and Jensen, S.: A model for estimating actual evapotranspiration from potential evapotranspiration, Nord. Hydrol., 6, 170-188, 1975.

Lee, J. G. and Heaney, J. P.: Estimation of urban imperviousness and its impacts on storm water systems, J. Water Resour. Pl. Manage.-ASCE, 129, 419-426, 2003.

Liu, Y. B. and De Smedt, F.: WetSpa Extension, A GIS-ased Hydrologic Model fior Flood Prediction and Watershed Management, Documentation and User Manual, Vrije Universiteit Brussel Department of Hydrology and Hydraulic Engineering, Brussel, 2004.

Muleta, M. K. and Nicklow, J. W.: Sensitivity and uncertainty analysis coupled with automatic calibration for a distributed watershed model, J. Hydrol., 306, 127-145, 2005.

Nash, J. E. and Sutcliffe, J. V.: River flow forecasting through conceptual models part I - A discussion of principles, J. Hydrol., 10, 282-290, 1970

NGI: Top10Vector, Nationaal Geografisch Instituut, Brussel, 2007.

Paul, M. J. and Meyer, J. L.: Streams in the urban landscape, Annu. Rev. Ecol. System., 32, 333-365, 2001.
Price, K.: Effects of watershed topography, soils, land use, and climate on baseflow hydrology in humid regions: A review, Prog. Phys. Geogr., 35, 465-492, 2011.

Ragab, R., Rosier, P., Dixon, A., Bromley, J., and Cooper, J. D.: Experimental study of water fluxes in a residential area: 2 . Road infiltration, runoff and evaporation, Hydrol. Process., 17, 2423 2437, 2003.

Refsgaard, A. and Storm, B.: Computer Models of Watershed Hydrology, chap. MIKE SHE, Water Resources Publications, Highlands Ranch, 809-846, 1995.

Refsgaard, J. C.: Parameterisation, calibration and validation of distributed hydrological models, J. Hydrol., 198, 69-97, 1997.

Refsgaard, J. C. and Knudsen, J.: Operational validation and intercomparison of different types of hydrological models, Water Resour. Res., 32, 2189-2202, 1996.

Roy, A. H. and Shuster, W. D.: Assessing impervious surface connectivity and applications for watershed management, J. Am. Water Resour. Assoc., 45, 198-209, 2009.

Rubarenzya, M. H., Graham, D., Feyen, J., Willems, P., and Berlamont, J.: A site-specific land and water management model in MIKE SHE, Nord. Hydrol., 38, 333-350, 2007.

Sahoo, G. B., Ray, C., and De Carlo, E. H.: Calibration and validation of a physically distributed hydrological model, MIKE SHE, to predict streamflow at high frequency in a flashy mountainous Hawaii stream, J. Hydrol., 327, 94-109, 2006.

Seiler, K. P. and Rivas, J. A.: Groundwater in the Urban Environment: Selected City Profiles, vol. 21 of IAH - International Contributions to Hydrogeology, chap. Recharge and discharge of the Caracas aquifer, Venezuela, Balkema Publishers, Rotterdam, 233-238, 1999.

Sheeder, S. A., Ross, J. D., and Carlson, T. N.: Dual urban and rural hydrograph signals in three small watersheds, J. Am. Water Resour. Assoc., 38, 1027-1040, 2002.

Shuster, W. D., Bonta, J., Thurston, H., Warnemuende, E., and Smith, D. R.: Impacts of impervious surface on watershed hydrology: A review, Urban Water J., 2, 263-275, 2005.

Simmons, D. L. and Reynolds, R. J.: Effects of urbanization on base-flow of selected south-shore streams, Long-Island, NewYork, Water Resour. Bull., 18, 797-805, 1982.

Smakhtin, V. U.: Low flow hydrology: a review, J. Hydrol., 240, 147-186, 2001.

Statistics Belgium: Population, Nationaal Instituut voor de Statistiek, Brussel, 2011.

Sun, G., Riekerk, H., and Comerford, N. B.: Modeling the hydrologic impacts of forest harvesting on Florida flatwoods, J. Am. Water Resour. Assoc., 34, 843-854, 1998.

Thompson, J. R., Sorenson, H. R., Gavin, H., and Refsgaard, A. Application of the coupled MIKE SHE/MIKE 11 modelling system to a lowland wet grassland in southeast England, J. Hydrol., 293, 151-179, 2004.

Vansteenkiste, T., Tavakoli, M., Ntegeka, V., Willems, P., De Smedt, F., and Batelaan, O.: Climate change impact on river flows and catchment hydrology: a comparison of two spatially distributed models, Hydrol. Process., 27, 3649-3662, 2013.

Walsh, C. J., Fletcher, T. D., and Ladson, A. R.: Retention Capacity: A Metric to Link Stream Ecology and Storm-Water Management, J. Hydrol. Eng., 14, 399-406, 2009.

Ward, R. and Robinson, M.: Principles of Hydrology, 3rd Edn., McGraw-Hill, Maidenhead, 1989. 
Willems, P.: A time series tool to support the multi-criteria performance evaluation of rainfall-runoff models, Environ. Model. Softw., 24, 311-321, 2009.

Willems, P. and Berlamont, J.: Probabilistic modelling of sewer system overflow emissions, Water Sci. Technol., 39, 47-54, 1999.

Wittenberg, H. and Aksoy, H.: Groundwater intrusion into leaky sewer systems, Water Sci. Technol., 62, 92-98, 2010.

Woldeamlak, S. T., Batelaan, O., and De Smedt, F.: Effects of climate change on the groundwater system in the Grote-Nete catchment, Belgium, Hydrogeol. J., 15, 891-901, 2007.
Xevi, E., Christiaens, K., Espino, A., Sewnandan, W., Mallants, D., Sørensen, H., and Feyen, J.: Calibration, Validation and Sensitivity Analysis of the MIKE-SHE Model Using the Neuenkirchen Catchment as Case Study, Water Resour. Manage., 11, 219-242, 1997.

Zhang, Z. Q., Wang, S. P., Sun, G., McNulty, S. G., Zhang, H. Y., Li, J. L., Zhang, M. L., Klaghofer, E., and Strauss, P.: Evaluation of the MIKE SHE model for application in the Loess Plateau, China, J. Am. Water Resour. Assoc., 44, 1108-1120, 2008. 